\title{
Identification of essential oil composition of four umbelliferae from Turkey
}

\author{
Sukru Hayta $^{1 *}$, Gulden Dogan $^{2}$, Azize Demirpolat $^{2}$, Eyup Bagci ${ }^{2}$
}

\begin{abstract}
Objective: Due to importance of essential oil composition of herbals the identification of essential oil composition of four umbelliferae were studied.

Material and Methods: The chemical composition of the essential oils of dried aerial parts of Ferulago angulata, Anthriscus nemorasa, Astrodaucus orientalis, Pimpinella peregrina were analysed by GC and GCMS.

Results: Forty eight, eighteen, fifty one and twenty components were identified representing 96.5\%, 85.9\%, $91.4 \%$ and $90.1 \%$ of the oils, respectively. The main compounds of Ferulago angulata were alpha-pinene (24.1\%), Beta-pinene (22.7\%), beta-phellandrene (20.5\%), alpha- phellandrene $(12.1 \%)$; the main compounds of Anthriscus nemorasa were Beta-caryophyllene (23.6\%), caryophyllene oxide (12.3\%), Sigma-cadinene $(12.1 \%)$, and trans pinocarveol (9.8\%); the main compounds of Astrodaucus orientalis were Alpha-pinene (29.6\%), Beta-pinene (21.5\%) and bicyclo(3.1.0)hex-2-ene (7.6\%)
\end{abstract}

Conclusion: The main constituents of Pimpinella peregrina trans-pinocarveol (35.1\%), peregijerene $(15.1 \%)$, Alpha-cubebene (12.4\%), (+) Epibicyclosesquiphellandrene (7.5\%), and Alpha-terpineol (6.7\%) were determined.

Keywords: Essential Oil, Chemotaxonomy, GC-MS, Ferulago angulata, Anthriscus nemorasa, Astrodaucus orientalis, Pimpinella peregrina

\section{Introduction}

The Apiaceae (formerly umbelliferae) is a large family of flowering and usually aromatic plants mostly growing in temperate areas. There are about 300 genera and 3000 species of this family worldwide (1). This family includes some of the commonly used vegetables and medicinal herbs such as carrot, celery, fennel, dill, anise, parsley, Angelica, caraway, coriander etc. Members of Apiaceae usually possess a characteristic pungent or aromatic smell which is due to the occurrence of essential oil or oleoresin in their different organs (2). Therefore, volatile oils of Apiaceae plants have a wide application in aromatherapy (3).

In the Flora of Turkey, the genus Ferulago is represented by 17 species (1). Ferulago angulata was divided into 2 subspecies by Chamberlain in 1987 . The known subspecies distributed in Turkey is F. angulata subsp. angulata; subsp. carduchorum differs from subsp. angulata by having scabrid inflorescence, ovarium, and leaves (not glabrous or subglabrous) (4). The genus Ferulago W.D.J.Koch is represented by 50 species worldwide, 32 of which are found in Turkey (17 species are endemic to Turkey).
Since Ferulago was revised for the Flora of Turkey (5), 3 new species and 1 new record have been added to the Flora of Turkey (6-8).

Ferulago angulata (Schlecht) Boiss is the common species of the genus distributed in the west and central parts of Iran. This plant grows in different areas of the word including Turkey, Greece, republic of Yugoslavia, Macedonia, Australia and Islamic republic of Iran. In Iran you can find it in the mountain in the west like Ariz in Sanandaj, Kooh Safid heights, Gere mountain in Chahar Mahale Bakhtiari and the most important source in the heights 2800-3200 $\mathrm{m}$ from the sea surface in Dena, parts of south Zagros mountains (9). The species was reported from north Iraq and southeast of Turkey, as well. Chevil is the common name and "oluklu caksir" Turkish name of this glabrous herb that reaches up to $150 \mathrm{~cm}$ in height. The herbs and spices of Ferulago angulata are used as flavors and antioxidants in food industry for century (10-11). The essential oil composition of Ferulago angulata (Schlecht) Boiss. (Apiaceae) aerial parts was determined.

Received: 07-12-2015, Accepted 14-12-2015, Available Online: 15-12-2015

1 Bitlis Eren University, Faculty of Engineering \& Architecture, Department of Environmental Engineering, Bitlis, Turkey

2 Firat University, Faculty of Science, Department of Biology, Elazig, Turkey

*Corresponding Author: Sukru Hayta E-mail: sukruhayta@hotmail.com 
In folk medicine, different species of Ferulago has been used in Turkey and Iran as sedative, tonic, remedy of digestive panics, aphoristic properties and haemorrhoids. Moreover, different parts of Ferulago species have been traditionally used against ulcers, snake bite and for treatment of headache and disease of the spleen $(9,12-13)$. Literature is available on the bioactivities of $\mathrm{F}$. angulata. These reports indicated the cytotoxic, antioxidant and antimicrobial potentials of the plant extracts and essential oil and It is also used in perfume and cosmetic industries (14-16).

The genus Anthriscus, commonly known as beaked chervil, beaked parsley, rough chervil, is one of the aromatic members of the Apiaceae family (17). The family of the Apiaceae is well known as a source of essential oils and a number of species are especially cultivated for it, like Pimpinella anisum L. and Anthriscus cerefolium L. Hofmm. (18).

The genus Anthriscus (Apiaceae) is represented with 8 species in Turkey flora. Anthriscus nemorosa (Bieb.) Sprengel is a perennial herb that grows in Europe and in parts of America, Africa, Asia and New Zealand (19-20). Anthriscus nemorosa is named local name "gimigimı" (21). It is reported that the plant parts are used in the preparation of the "otlu peynir" famous cheese around the Van province in Eastern Anatolian region (22). Some of Antriscus plants have been traditionally used by local people as herbal drugs. The dried root of A. sylvestris is used in Korean and Chinese traditional medicine for the treatment of various diseases (1). It is known as chervil. Chervil is used for culinary purposes, and in folk medicine, for inflammations, as depurative, diuretic and hypotensive. Extracts of chervil has possess antiinflammatory, antifungal, spasmogenic, spasmolytic activities, and negative inotropic effect (23). There is no more study on the essential oils of A. nemorosa in Turkey and there are two study from Serbia and Iran in the world.

The genus Astrodaucus Drude is belonging to Apiaceae family that is represented with one species in Turkey flora (1). This study is the only species in the country of the genus Astrodaucus in Astrodaucus orientalis (L.) qualitative and quantitative composition of the essential oil of its kind in the drum, oil yield has demonstrated and economical aims to provide basic data on availability issues.

Astrodaucus orientalis is named local name "Havyıldız" and it is an aromatic herb (10) It has potential of anticancer activity of A. orientalis extracts and one of its possible mechanisms of action on cancer cell antiproliferation (24). This aromatic plant is traditionally used as a salad, vegetable and a food additive in some parts of Iran and Turkey (25).

Pimpinella is a member of the Apiaceae and comprises approximately 150 species distributed in the northern hemisphere (26). Pimpinella is represented in Turkey by 23 species ( 5 endemic), 2 subspecies and 2 varieties, representing a total of 27
(1). This genus is well known for a number of medicinally and pharmaceutically important species, P. anisum being the most notable one (27).

One important criterium for studying the oils of this genus is the fact that they contain $\mathrm{C} 12$ sesquiterpenoids and phenylpropanoids with a unique structure and their biological activities may have potential for developing newagents for use in agriculture and medicine (27-28).

The most widely known and cultivated Pimpinella species is like that Pimpinella anisum (Anis) fruits (Aniseed) have been used in Turkish folk medicine as carminative, appetizers, sedative, and agents to increase milk secretion (29).

It is aimed that to determine the essential oils of the four species and compared with the genus patterns. The results also will be give some clues on the usability of the plant and essential oils for different purposes.

\section{Materials and Methods}

\section{Plant Source}

Ferulago angulata, specimens were collected from natural habitats in Bitlis-Hizan; in 2014; Anthriscus nemorasa, specimens were collected in Bitlis-Hizan, in 2014; Astrodaucus orientalis specimens were collected in Elazig-Harput, in 2014 and Pimpinella peregrina specimens were collected from BitlisHizan, 2014. Four voucher specimens were deposited in the Firat University Herbarium (FUH) under registration numbers Hayta 4818, Hayta 4829, Hayta 4835 and Hayta 4826 respectively.

\section{Extraction of the essential oil}

The essential oil was extracted by hydrodistillation using a modified Clevenger apparatus coupled to a $2 \mathrm{~L}$ round-bottom flask. A total of $100 \mathrm{~g}$ of fresh plant material (aerial parts) and $1 \mathrm{~L}$ of water were used for the extraction. The chemical analysis were performed in Firat University, Sci. Fac., Biology Deprt., Plant Products and Biotechnology Res. Lab. The extraction was performed over 3 hour period. Subsequently, the hydrolate was collected and centrifuged at 10,000 rpm for 10 minutes. The organic phase was removed with the aid of a Pasteur pipette, and subsequently transferred to an black coloured vials, wrapped in parafilm and aluminum foil and $4{ }^{\circ} \mathrm{C}$ under refrigeration until analysis. The yields of oils were calculated on the basis of the dry mass.

\section{Gas Chromatographic (GC) Analysis}

The essential oil was analysed using HP 6890 GC equipped with FID detector and HP- 5 MS (30 m x $0.25 \mathrm{~mm}$ i.d., film tickness $0.25 \mu \mathrm{m}$ ) capillary column was used. The column and analysis conditions were the same as in GC-MS expressed as below. The percentage composition of the essential oils was computed from GC-FID peak areas without correction factors. 
Gas chromatography / Mass spectrometry (GCMS) analysis

GC-MS analyses of the oils were performed on a Hewlett Packard Gas Chromatography HP 6890 interfaced with Hewlett Packard 5973 mass spectrometer system equipped with a HP 5-MS capillary column $(30 \mathrm{~m} \times 0.25 \mathrm{~mm}$ id, film thickness $0.25 \mu \mathrm{m})$. The oven temperature was programmed from $70-240^{\circ} \mathrm{C}$ at the rate of $5^{\circ} \mathrm{C} / \mathrm{min}$. The ion source was set at $240^{\circ} \mathrm{C}$ and electron ionization at $70 \mathrm{eV}$. Helium was used as the carrier gas at a flow rate of 1 $\mathrm{mL} / \mathrm{min}$. Scanning range was 35 to 425 amu. Diluted oil in $n$-hexane $(1.0 \mu \mathrm{L})$ was injected into the GC-MS The identification of constituents was performed on the basis of Retention Indices (RI) determined by coinjection with reference to a homologous series of $n$ alkanes, under identical experimental conditions. Further identification was performed by comparison of their mass spectra with those from NIST 98 Libraries (on ChemStation HP) and Wiley 7th Version. The relative amounts of individual components were calculated based on the GC (HP5MS column) peak area (FID response) without using correction factors. The identified constituents of the essential oils are listed in Table 1.

\section{Results and Discussion}

The water distilled essential oil of the plant was analysed by GC, GC-MS system. In the result of analysis, forty eight compounds were identified representing $96.5 \%$ of the oils. The main compounds of Ferulago angulata were $\alpha$-pinene $(24.1 \%), \beta$ pinene $\quad(22.7 \%), \quad \beta$-phellandrene $(20.5 \%), \quad \alpha$ phellandrene $(12.1 \%)$. Monoterpenes were the main class of essential oil of Ferulago angulata (ca. 80$85 \%$ ). The results has shown that the parts of the plant and essential oil may be used as natural product and food additive. $\alpha$-phellandrene $(24.2 \%), \quad \beta$ phellandrene $(14.9 \%), \alpha$-pinene $(14.7 \%)$ and pcymene $(10.3 \%)$ were the main components of the oils obtained from the Ferulago angulata in Iran (30). Similarly, in present analyses results showed that $\alpha$ phellandrene, $\beta$-phellandrene and $\alpha$-pinene were the major component of the essential oils from Turkey samples

In this study, hydro-distilled essential oils derived from the aerial parts of Anthriscus nemorosa (Bieb.) Sprengel grown in Turkey naturally were analysed by GC and GC-MS. The essential oil yield was determined as $0.2(\mathrm{v} / \mathrm{w})$. Among eighteen compounds identified (representing $85.9 \%$ of the total oil), the main components were: $\beta$-caryophyllene $(23.6 \%)$, caryophyllene oxide $(12.3 \%), \delta$-cadinene $(12.1 \%)$, and trans pinocarveol $(9.8 \%)$. Essential oil analysis of the Anthriscus nemorosa has shown that it has $\beta$ caryophyllene chemotype from the Eastern Anatolian Region. Pavlovic et al. (2011) (31), found 62 compounds in the roots of Anthriscus nemorosa identified (representing $89.0 \%$ of the total oil), the main components were: n-nonane $(12.1 \%)$, nhexadecanol $(6.9 \%)$, delta-cadinene $(6.4 \%)$, beta pinene $(6.0 \%)$ and germacrene $\mathrm{D}(5.4 \%)$. Our analysis results were not similar with this study findings, because of the absent of the major components (except delta-cadinene) in present samples.

The volatile oil composition of Pimpinella peregrine L. (APIACEAE) were collected from the Bitlis. It is named as "El Anasonu" in Turkish. The essential oil were obtained by hydrodistillation in Clevenger-type apparatus, and chemical analyses were performed by GC and GC-MS. The essential oil yield was $0.3(\mathrm{v} / \mathrm{w})$, from the aerial parts of the Pimpinella peregrina. A total of 20 different compounds were identified representing $90.1 \%$ of the oils. The main constituents of Pimpinella peregrina trans-pinocarveol (35.1\%), peregijerene $(15.1 \%), \quad \alpha$-cubebene $(12.4 \%), \quad(+)$ epibicyclosesquiphellandrene $(7.5 \%)$, and $\alpha$-terpineol $(6.7 \%)$ were determined. The characteristic phenylpropanoids in Pimpinella oils, a number of other $C_{12}$ sesquiterpenes such as geijerene and azulene were also present in considerable amounts (32-33). From a chemotaxonomic stand point, $\mathrm{C}_{12}$ sesquiterpenes and phenylpropanoids are characteristic to the genus Pimpinella and are phytochemical markers for this genus that separates them from all the other Apiaceae investigated thus far. These components were detected in our samples.

The composition, percentage and retention indices of components of the oil were listed in Table 1 . The essential oil yield is $0.2(\mathrm{v} / \mathrm{w})$, from the aerial parts of the Astrodaucus orientalis. Fourty nine constituents were comprised the $91.4 \%$ of the total oil. The predominant compounds of Astrodaucus orientalis were determined as $\alpha$-pinene $(29.6 \%), \beta$-pinene $(21.5 \%)$ and bicyclo(3.1.0)hex-2-ene (7.6\%). Mirza et al. (2003) (34) reported that major components of the leaf oil were fenchyl acetate $(44.5 \%)$ and $\boldsymbol{\alpha}$-pinene $(21.6 \%)$ but the major constituents of the seed oil were myrcene $(47.7 \%)$ and $\boldsymbol{\beta}$-pinene $(21.8 \%)$ from Iran. Present analysis results were similar with this study findings but the major constituents (myrcene and fenchyl acetate) were not detected in our samples. Overall, the essential oil composition was found to be similar for the different parts of the plant studied regarding the major monoterpenes ( $\alpha$-pinene and $\beta$ pinene) and also minor monoterpenes between Astrodaucus orientalis and Ferulago angulata. However, many differences were determined among the other terpenic compounds. For the different parts analysed, $\alpha$-pinene and $\beta$-pinene were found as major compounds in essential oils of Astrodaucus orientalis and Ferulago angulata but not in Anthriscus nemorosa and Pimpinella peregrina oils. Qualitative and quantitative differences were reported in these species essential oils reported and these may be due to the genetic, differing chemotypes, drying conditions, mode of distillation and/or extraction and geographic or climatic factors. 
Table 1. Constituents of the essential oil from of four Apiaceae

\begin{tabular}{|c|c|c|c|c|c|c|}
\hline No & Compounds & RI & F.angulato & A.nemorosa & A.orientalis & P.peregrina \\
\hline 1 & Heptenal & 850 & 0.1 & - & 0.1 & - \\
\hline 2 & Hexenal & 935 & - & - & 0.1 & - \\
\hline 3 & Bicyclo(3.1.0)hex-2-ene & 1016 & 0.2 & - & 7.6 & - \\
\hline 4 & $\alpha$-Pinene & 1021 & 24.1 & 0.5 & 29.6 & - \\
\hline 5 & Camphene & 1034 & 0.3 & - & 3.3 & - \\
\hline 6 & Verbenene & 1038 & - & - & 0.1 & - \\
\hline 7 & Sabinene & 1052 & 1.5 & 1.7 & 2.5 & 0.3 \\
\hline 8 & $\beta$-Pinene & 1056 & 22.7 & 0.5 & 21.5 & - \\
\hline 9 & $\beta$-Myrcene & 1065 & 2.4 & - & 3.5 & - \\
\hline 10 & $\alpha$-Phellandrene & 1077 & 12.1 & 0.4 & - & - \\
\hline 11 & $\alpha$-Terpinene & 1085 & 0.1 & - & 0.1 & - \\
\hline 12 & p-Cymene & 1090 & 3.2 & - & 0.5 & - \\
\hline 13 & dl-Limonene & 1096 & - & - & 2.7 & 0.1 \\
\hline 14 & Cis-Ocimene & 1097 & - & - & 0.4 & - \\
\hline 15 & $\beta$-Phellandrene & 1098 & 20.5 & - & - & - \\
\hline 16 & $\beta$-Ocimene & 1107 & 0.5 & 1.0 & 0.1 & 0.2 \\
\hline 17 & $\gamma$-Terpinene & 1116 & 0.3 & - & 0.4 & 0.1 \\
\hline 18 & p-Cresol & 1128 & 0.1 & - & - & 0.1 \\
\hline 19 & $\alpha$-Terpinolene & 1136 & 0.7 & - & 0.2 & - \\
\hline 20 & Benzene-1-methy-4 & 1139 & 0.1 & - & - & - \\
\hline 21 & Linalool & 1146 & - & - & - & 0.1 \\
\hline 22 & Bicylo[3.1.0] hex-2-one & 1166 & 0.1 & - & - & - \\
\hline 23 & Allo-Cymene & 1170 & - & - & - & 4.0 \\
\hline 24 & Trans-Pinocarveol & 1177 & 0.2 & 9.8 & - & 35.1 \\
\hline 25 & Trans-Verbenol & 1180 & - & - & 0.6 & - \\
\hline 26 & 2,5-Diethythiophene & 1194 & 1.7 & - & - & - \\
\hline 27 & Borneol & 1199 & - & - & - & - \\
\hline 28 & 3-Cyclohexen-1-ol & 1203 & 0.3 & 0.8 & 0.7 & 0.6 \\
\hline 29 & Ethanone & 1207 & - & - & - & \\
\hline 30 & $\alpha$-Terpineol & 1214 & 0.6 & 2.7 & - & 6.7 \\
\hline 31 & Fenchyl acetate & 1215 & - & - & 5.3 & - \\
\hline 32 & 1,3-Cylohexadiene & 1245 & 0.1 & - & - & - \\
\hline 33 & Chrysanthenyl acetate & 1251 & - & - & 0.2 & - \\
\hline 34 & Bornyl acetate & 1280 & - & - & 2.5 & \\
\hline 35 & Thymol & 1286 & 0.5 & - & - & 0.2 \\
\hline 36 & 2H-1-Benzopyran & 1288 & - & - & 0.2 & - \\
\hline 37 & Peregijerene & 1290 & - & 2.0 & - & 15.1 \\
\hline 38 & Carvacrol & 1293 & 0.2 & - & - & - \\
\hline 39 & 2,4-Decadienal & 1310 & - & - & 0.1 & - \\
\hline 40 & $\alpha$-Longipinene & 1343 & - & - & 0.1 & - \\
\hline 41 & $\alpha$-Cubebene & 1358 & - & - & 0.1 & 12.4 \\
\hline 42 & $\alpha$-Copaene & 1360 & 0.1 & - & 0.6 & - \\
\hline 43 & $\beta$-Bourbonene & 1364 & - & - & 0.4 & - \\
\hline 44 & [+]-Epibisesquiphellandrene & 1367 & - & - & 0.8 & 7.5 \\
\hline 45 & $\beta$-Elemene & 1369 & - & 4.2 & - & - \\
\hline 46 & Ethanone & 1385 & - & - & 0.1 & - \\
\hline 47 & Caryophyllene & 1391 & 0.1 & 23.6 & 0.3 & - \\
\hline 48 & $\beta$-Caryophyllene & 1393 & - & - & - & 0.9 \\
\hline 49 & $\gamma$-Elemene & 1097 & 0.1 & - & - & - \\
\hline 50 & $\alpha$-Farnesene & 1399 & - & 1.0 & - & - \\
\hline 51 & $\beta$-Cubebene & 1401 & 0.1 & - & 0.1 & \\
\hline 52 & Trans- $\beta$-Farnesene & 1416 & 0.1 & - & - & - \\
\hline 53 & $\alpha$-Humulene & 1418 & 0.1 & - & 0.7 & - \\
\hline 54 & Aromadendrene & 1421 & 0.4 & - & - & - \\
\hline
\end{tabular}




\begin{tabular}{|c|c|c|c|c|c|c|}
\hline 55 & $\beta$-Cubebene & 1433 & 0.1 & - & - & - \\
\hline 56 & Germacren D & 1435 & 0.4 & 5.6 & 0.8 & 0.3 \\
\hline 57 & Valencene & 1442 & - & 0.6 & - & 0.4 \\
\hline 58 & Bicylogermacrene & 1445 & 0.1 & - & - & - \\
\hline 59 & $\alpha$-Selinene & 1446 & 0.1 & - & - & - \\
\hline 60 & $\alpha$-Amorphene & 1456 & 0.1 & - & - & - \\
\hline 61 & $\delta$-Cadinene & 1458 & 0.1 & 12.1 & 0.5 & - \\
\hline 62 & Cis- $\alpha$-Bisabolene & 1470 & 0.1 & - & - & - \\
\hline 63 & $\alpha$-Calacorone & 1472 & - & - & 0.1 & - \\
\hline 64 & Germacren b & 1482 & 0.2 & - & 0.7 & - \\
\hline 65 & Cadala-(10)-3,8,triene & 1484 & - & - & 0.1 & - \\
\hline 66 & Spathulenol & 1493 & - & - & 0.7 & 1.8 \\
\hline 67 & Caryophyllene oxide & 1496 & - & 12.3 & 0.6 & 1.1 \\
\hline 68 & Salvial-4-(14)-en-one & 1502 & - & - & 0.1 & - \\
\hline 69 & Carotol & 1508 & - & 6.2 & - & - \\
\hline 70 & Bergamotone $\alpha-Z$ & 1511 & - & 0.9 & - & - \\
\hline 71 & Crypton & 1512 & - & - & 0.1 & - \\
\hline 72 & Humulene epoxide & 1515 & - & - & 0.2 & - \\
\hline 73 & Trans- $\beta$-Caryophyllene & 1521 & 0.1 & - & - & - \\
\hline 74 & Tau-Muurolol & 1532 & 0.3 & - & - & - \\
\hline 75 & $\alpha$-Cadinol & 1538 & 0.1 & - & - & - \\
\hline 76 & Calarene & 1536 & - & & 0.5 & - \\
\hline 77 & $\beta$-Humulene & 1547 & 0.1 & - & - & - \\
\hline 78 & $\alpha$-Bisabolol & 1554 & 0.6 & - & - & - \\
\hline 79 & Dehydroaromadendrene & 1558 & 0.1 & - & 0.2 & - \\
\hline 80 & Benzyl benzoate & 1596 & 0.1 & - & - & - \\
\hline 81 & Benzoic acid & 1602 & - & - & - & 3.1 \\
\hline 82 & 2-Pentadeconene & 1629 & - & - & 0.2 & - \\
\hline 83 & n-Hexadecanoic acid & 1689 & - & - & 0.1 & - \\
\hline 84 & Ar-curcumene & 1790 & - & - & 0.1 & - \\
\hline 85 & $\alpha$-Toluene & 1852 & - & - & 0.1 & - \\
\hline 86 & Tricosane & 1889 & 0.1 & - & - & - \\
\hline 87 & Heptacosane & 1899 & - & - & 0.2 & - \\
\hline \multicolumn{3}{|c|}{ Total } & 96.5 & 85.9 & 91.4 & 90.1 \\
\hline
\end{tabular}

Conflict of Interest: The authors declare that, there are no conflicts of interest between the authors. The authors alone are responsible for the content and writing of the paper.

\section{References}

1. Davis, P. H. Flora of Turkey and the East Aegean Islands. University Press, Edinburgh. 4 (1972) 323.

2. Singh, V., Jain, D.K. Taxonomy of angiosperms. 6 th ed India: Rastogi Publications. (2007) 298.

3. Janardhanan, M. Herb and spice essential oils. Discovery publishing house, New-Delhi. (2004) 23.

4. Ozhatay, N., Akalın, E. A new Ferulago (Umbelliferae) from NW Turkey. Botanical Journal of the Linnean Society. 133 (2000) 353-342.

5. Peșmen, H. Potentilla L. In: Davis PH, editor. Flora of Turkey and the East Aegean Islands, Vol. 4. Edinburgh, UK: Edinburgh University Press, (1972) 41-68.
6. Akalın, E., Pimenov, M. Ferulago trojana (Umbelliferae), a new species from western Turkey. Botanical Journal of the Linnean Society. 146 (2004) 499-504.

7. Pimenov, M.G., Leonov, M.V. The Asian Umbelliferae Biodiversity Database (ASIUM) with particular reference to South-West Asian taxa. Turkish Journal of Botany. 28 (2004) 139-145.

8. Kandemir, A., Hedge, I.C. An anomalous new Ferulago (Apiaceae) from eastern Turkey. Willdenowia. 37 (2007) 273-276.

9. Sodefian, G., Ansari, K., Bamoniri, A., Mirjalili, B. Study of chemical composition of Ferulago angulata (Schelchet) Boiss from Iran using supercritical fluid extraction and nano sale injection. Dig J Nonomat Biostruct. 6 (2011) $162-168$. 
10. Guner, A., Aslan, S., Ekim, T., Vural, M., Babaç, M.T. (edlr.). Türkiye Bitkileri Listesi (Damarlı Bitkiler). Nezahat Gökyiğit Botanik Bahçesi ve Flora Araştırmaları Derneği Yayını. İstanbul ( 2012)

11. Hedge, I.C. Flora Iranica. Vol. 162. Graz: Akademische Druke Verlgsanstalt (1987).

12. Oztürk, B., Gür, S., Coskun, M., Kosan, M., Erdurak, C., Hafez, C., Ozgunes, G., Cetinkaya, M. Relaxant effect of Ferulago syriaca root extract on human corpus cavernosum. Eur Urol Suppl. 3 (2004) 62.

13. Khalighi-Sigaroodi, F., Hadijiakhoondi, A., Shafiee, A., Mozaffarian, V.A., Shahverdi, A.R., Alavi, S.H.R. Phytochemical analysis of Ferulogo bernardii Tomk \& M. Pimen. Daru. 14 (2006) 214-221.

14. Basile, A., Sorbo, S., Spadaro, V., Bruno, M., Maggio, A. Faraone, N., Rosselli, S. Antimicrobial and antioxidant activities of coumarins from the roots of Ferulago campestris (Apiaceae). Molecules. 14 (2009) 939-952.

15. Taran, M., Ghasempour, H.R., Shirinpour, E. Antimicrobial activity of essential oils of Ferulago angulata subsp. carduchorum. Jundishapur Journal of Microbiology. 3 (2010) 10-14.

16. Zare, F., Valiyari, S., Azadmehr, A., Hajiaghaee, R., Bandehagh, A., Baradran, B. Cytotoxic activities of Ferulago angulata on human leukemia and lymphoma cells by induction of apoptosis. J Med Plants Res. 7 (2013) 677682.

17. Nickavar, B., Mojab, F., Mojahedi, A. Composition of the essential oil from Anthriscus nemorosa. Chemistry of Natural Compounds. 45 (2009) 443-444.

18. Hendrawati, O., Woerdenbag, J., Hille, J. Seasonal variations in the deoxypodophyllotoxin content and yield of Anthriscus sylvestris L. (Hoffm.) grown in the field and under controlled conditions. J.Agri Food Chem. 59 (2011) 8132-8139.

19. Magnússon, S.H. Nobanıs Invasive Alien Species Fact Sheet Anthriscus sylvestris From: Online Database of the North European and Baltic Network on Invasive Alien Species - NOBANIS. Available from: $<$ www.nobanis.org $>$.(accessed 19.08.2011).

20. Hulten, E., Fries, M. Atlas of North European Vascular Plants North of the Tropic of Cancer. Koeltz Scientific Books, Konigstein (1986)

21. Altundag, E., Ozturk, M. Ethnomedicinal studies on the plant resources of east Anatolia, Turkey. The 2nd International Geography Symposium GEOMED2010. Procedia Social and Behavioral Sciences 19 (2011) 756777.
22.

Zci, Z., Coskun, H., Tuncturk, Y. Some Properties of Fresh and Ripened Herby Cheesea Traditional Variety Produced in Turkey. Properties of Herby Cheese, Food Technol. Biotechnol. 42 (2004) 47-50.

23. Fkdmini, G., Bilia, A. R., Breschi, M. C., Martinotti, E., Norelli, I. Anthriscus cerefolium phytochemical and pharmacological study. Pharmacol. Res., Sol. (1993) 3334.

24. Abdolmohammadi, M. H., Fouladdel, S., Shafiee, A., Amin, G., Ghaffari, S. M., Azizi, E. Antiproliferative and apoptotic effect of Astrodaucus orientalis (L.) drude on T47D human breast cancer cell line: Potential mechanisms of action. African Journal of Biotechnology. 8 (2009) 4265-4276.

25. Nazemiyeh, H., Razavi, S.M., Delazar, A., Asnaashari, S., Khoi, N.S., Daniali, S., Nahar, L., Sarker, S. D. Distribution Profile of Volatile Constituents in Different Parts of Astrodaucus orientalis (L.) Drude Rec. Nat. Prod. 3 (2009) 126-130,

26. Heywood, V.H. The Biology and Chemistry of the Apiaceae, Linnean Society of London, London, p. 232, (1971).

27. Tabanca, N., Bedir, E., Ferreira, D., Slade, D., Wedge, D.E., Jacob, M.R., Khan, S.I., Kirimer, N., Baser, K. Khan, I.A. Bioactive constituents from Turkish Pimpinella species. Chemistry and Biodiversity. 2 (2005a) 221-232.

28. Kubeczka, K.H., Baser, K.H.C., Kirimer, N. (Eds.), Proceedings of the 28th International Symposium on Essential Oils, Eskisehir, Turkey, 1-3 September, (1997) p. 35

29. Baytop, T. Turkiye'de Bitkilerle Tedavi, Nobel Tip Kitapevi, Istanbul, 1999, p. 149.)

30. Akhlaghi, H. Chemical Composition of the Essential Oil from the Aerial Parts of Ferulago angulata (Schlecht.) Boiss. from Northeast Iran. Jeobp. 11 (2008) 544 - 547.

31. Pavlović, M., Petrović, S., Milenković, M., Couladis, M., Tzakou, O., Niketić, M. Chemical composition and antimicrobial activity of Anthriscus nemorosa root essential oil. Natural product communications. 6 (2011) 271-273.

32. Kubeczka, K.H., Bohn, I., Schultze, W., Naturforsch, Z. 44 (1989) 177.

33. Velasco-Negueruela, A., Perez-Alonso, M.J., Perez de Paz, P.L., Pala-Paul, J., Sanz, J. Chromatogr. A. 1011 (2003) 241.

34. Mirza, M., Baher, Z., Dini, M. Chemical composition of the essential oils of Astrodaucus orientalis (L.) Drude leaves and seeds. Flavour and Fragrance Journal. 18 (2003) 205-206.

Copyright (C) 2014 The Author(s); This is an open-access article distributed under the terms of the Creative Commons Attribution License (http://creativecommons.org/licenses/by/4.0), which permits unrestricted use, distribution, and reproduction in any medium, provided the original work is properly cited. All Rights reserved by international journal of Natural Science and Discovery 